\title{
THE INFLUENCE OF SERVICE BRANDING PERCEPTION ONCUSTOMER SATISFACTION OF LOW COST AIRLINES:AIR ASIA AND MALINDO AIR
}

\author{
Amran Harun ${ }^{1}$, Mohd Nizam S. Ashraff ${ }^{2}$, David Martin ${ }^{3}$, Nur Aniza Quantaniah Jusoh ${ }^{4}$, \\ Umi Kartini Rashid ${ }^{5}$ \\ 1,3,4,5 Universiti Tun Hussein Onn Malaysia \\ ${ }^{2}$ Universiti Malaysia Sabah \\ *Corresponding E-mail : amranh@uthm.edu.my
}

\begin{abstract}
The main challenge of low cost airline such as Air Asia and Malindo Air is to make the brand of the airline echoes with quality. Both airlines are perceived differently even though they are in the same industry due to their branding efforts. Thus, this study aims to understand the relationships of service branding (amenities, word-of-mouth, employee, feelings, reliability and publicity) with customer satisfaction amongst Air Asia and Malindo Air customers. A total of 270 questionnaires were distributed to the customers in the airport through a convenience sampling. The multiple regression analysis indicated only three variables of service branding have significant relationships with customer satisfaction namely amenities, word of mouth and employee. Low cost airlines in general will find this data or information helpful particularly in their endeavour to best serve their customers through service branding efforts which in the long run will help them to sustain and expand their business to another level.
\end{abstract}

Keywords: Islamic microfinance, zakat, waqf, cost, affordability

DOI: https://doi.org/10.30880/jtmb.2018.05.03.008

Received: August 16, 2018

Accepted: September 25, 2018

Published: December 15, 2018

\subsection{Introduction}

A number of researches have compared full services airlines with low cost carriers (eg: Wong and Musa ; 2011), O'Connell and Williams; 2005), Sørensen; 2005). This recent study however examine the services of two low cost carriers, namely, Air Asia and Malindo Air. Air Asia commenced their low cost services in 1996 and it is now one of the world's best low cost carriers, connecting most of the Asean countries to the world. Its slogan "Everyone Can Fly" gave a tremendous stir in the airline industry especially in Malaysia. Whereas, Malindo Air, was founded recently in 2012. The parent companies of Malindo Air are National Aerospace and Defence Industries Sdn Bhd (Malaysia) and Lion Air (Indonesia). The brand quickly became one of the fastest growing companies in the respective industry. The emergence of Malindo Air with the slogan "Not Just Low Cost" proves that there is more to this than what its rival; Air Asia is offering.

In the local context, Wong and Musa (2011), in their research, provided a comparison between Air Asia and Malaysia Airlines. It was definitely an interesting study, however, it was sort of incompatible in a sense that each airline is using a different business model. The fact that Malaysia Airlines is a full service airline, on the other hand, Air Asia is operating its business as a low cost airline. To close the gap, hence, in this current research, AirAsia and Malindo Air will be studied as they are competing in the same low cost airline industry.

Low Cost Carrier or LCC can be defined as an airline that provides air transportation, point-topoint network (focuses on Origin and Destination), employees work multiple roles and most 
importantly they provide no frills services. Low Cost Carrier (LCC) is sometimes called as Low Fare Airlines (LFA). A study of this magnitude is important so that local LCC providers might have a better understand of their passengers' needs. In addition to that, LCC provider can perhaps re-evaluate their ways of achieving customer satisfaction through the understanding of what really matter in achieving customer or passenger satisfactions. As purported by Jorre (2013), LCC model are constantly challenged and evolving according to their passengers. The industry is quite homogenous in nature, and most of the major players in the industry are focusing on price based competition, which affects their financial performance (Morrison \& Winston, 1996). According to Jensen (2009), the main challenge for LCC companies is to avoid being perceived as 'just another budget airline with poor services.' Basically the challenge is to make the brand of the airline echoes with quality that enables passengers to be loyal and perceived it as a good service airline.

Both Air Asia and Malindo Air are perceived differently even though they are in the same industry (low cost carrier) due to their branding efforts. With that in mind, this research aims to understand the influence of brand service perception towards customer satisfaction. It is important to understand this as the information can help low cost airlines to tailor their marketing mix as well as using their marketing budget in the most effective way. Significantly, Malindo Air had recently provided new amenities that might change the low cost carrier's industry. Thus, it is important to see whether this new approach will have an impact on the LCC model or not. By indulging in price war also, they are increasing their leverage to finance the business to magnify the gains. But it can also magnify their losses if they were to fail in their attempts.

To further establish important grounds of this research, it is important to unravel the concept of service brands. This is because, airlines industry belongs to service industry, and profit oriented organization nowadays has already accepted and adapted the idea of branding their services. Branding their services can help boost their performance with regards to gaining profit in general as well as ensuring sustainability of the organization as well as the services itself. Services branding is almost identical to product branding in a broader sense (White, 2012). However, close inspection reveals that both terms are different in most crucial ways. Product branding is basically all about the product, however, service brand is all about people and interaction needed to close the deal. Service brand largely depends on vast experience of employees. In LCC industry's contexts, they have the ground staff to deal with everyday customers (passengers) and also inflight staff (steward, stewardess and pilots). In this study, service branding is a multi-dimensional variable comprising amenities, word-of-mouth, employee, feelings, reliability and publicity. Thus, this study will examine the influence of service branding on customer satisfaction among Air Asia and Malindo Air customers.

\subsection{Literature Review}

\subsection{Customer Satisfaction}

Customer Satisfaction can be described as a measure for services or goods provided by business entities managed to surpass the consumer's expectation for the goods or services (Farris, Bendle, Pfeifer and Reibstein, 2010). It can be further explained as when a number or percentage of customer agrees that the goods or services offered exceed their specified satisfaction goals. Customer satisfaction is important to marketer because, through customer satisfaction, marketer can ensure profit maximization due to the fact that it can help increase of sales which will eventually lead to loyalty among customers, recommendation and repeat purchase (Wilson, Zeithaml, Bitner, and Gremler, 2008). Wicks and Roethlein (2009) also mused the idea that marketers who consistently achieved customer satisfaction enjoy higher retention levels and greater profitability as a results from an increased in customer loyalty. Alternatively, customers that constantly experienced satisfaction towards a service will create a preference towards the particular brand and ultimately become attached to the specific brand (Larreche, 1998). In regards to dissatisfaction, there is some evidence that suggested dissatisfied consumers tend to give 
negative feedback or word-of-mouth. It cannot be assumed that those who are satisfied will only be the ones talking (Anderson, 1998). In LCC model, word-of-mouth plays a rather significant role in creating a consensus in terms of perception towards a particular 'brand' of airlines.

\subsection{Services Branding}

Services can be defined as a form of economic activity. It is intangible in nature, in contrast to its counterpart, goods, that is tangible in nature. Since it is intangible, the only way to measure it is through experience. Good experience indicates a well execute services. In this research context, services refer to the operation of a LCC. Services branding refers to the brand of services. Every brand if carefully invested upon will provide the company with a more clear and defined services. It will certainly make it easier for the company to generate preference among consumers and it can also help business entities to add value to the services. In some cases the businesses can demand for premium prices. Services branding is important because it can influence how consumer perceived the services. If it is designed carefully, it can reflect the consumer's personality or preferences. When that happened, consumers will likely to purchase that service and if the service can meet with the expectations of the consumer, customer satisfaction is achieved. Below are the list of dimensions for services branding

\subsubsection{Feeling}

'Feeling' refers to the state of mind of the passengers. Passengers have positive and negative feelings when they are engaged with the services. Positive feelings may arise when they achieved satisfaction while negative feelings are formed when they are not satisfied with the services provided (Price, Amould and Deibler, 1995). According to Muhammad, Kalthom and Ali (2013), there is a significant positive impact of satisfied customer to word-of-mouth. It was also found that pursuing customer satisfaction is imperative as means of word-of-mouth has widened. Examples of platform for word-of-mouth to travel are social media such as Facebook, Twitter, Youtube and other forum based websites. Other than that knowledge websites such as Wikipedia are also being utilized as a platform to spread the good words. But there are other researchers who contemplated that passengers of LCC tend not to complaint when the airline failed to live up to their expectation (Wittman, 2014). This is due to the low price factor as passengers already set a low expectation even before engaging with the airlines. They feel that, they experience what they paid for.

Feelings constitutes of the emotions that customers feel during before and after purchase of a service or product. Feelings can be positive or negative in nature. It depends really on how the customers feel as a whole. Price et al. (1995) indicated that those organization or companies that took extra measures in ensuring their clients comfort may be perceived as superior in nature. Wen and Yeh (2010) stated that safety issues is the most applicable with regards to feelings. Therefore, based on previous findings on feelings, this study hypothesizes that:

\section{H1: There is a significant positive relationship between feelings and customer satisfaction.}

\subsubsection{Employee}

Employee is perhaps one of the most important part of a service brands. This is because staff or employees are the bridge between the consumers and the company itself. This means that consumer's first impression towards the company is through the employees. According to Gronroos (1994), employees represent the service brands and the whole image of the company. In Low Cost Carrier perspective, passengers assume that the employees are the bearer of the brands of the service and their level of efficiency will determine whether the passengers are satisfied or not. Furthermore, each employee represents the organization and through them, it defines the whole concept of the establishment's services and products (Shostack, 1997). Employees is such 
an important factor studied in a recent airline research (Saha and Theingi, 2009; Wen and Yeh, 2010)).

In terms of the relationship between employee and customer satisfaction, there have been a few extensive researches have been conducted before such as Iaffaldano and Muchinsky (1985) and Mathieu and Zajac (1990). But these researches have indicated that although the relationship is positive, the relationship itself was very minimal and weak. This relationship corresponded with customer satisfaction and job-related attitudes. However, other researches have found that customer satisfaction does correlate with employee attitudes and their performance (Wiley, 1990; Zeithaml, Parasuraman and Berry, 1985).

The relationship was further explained as some kind of symbiotic relationship. If customer satisfaction is jeopardized, most probably the service provider has a problem in handling and communicating with its employees. As illustrated by Adsit, London, Crom and Jones (1996), in today's competitive environment, it is important for the management of the service provider to tie customer values to the organizational strategies and communicating the strategies to employees in the form of goals and expectations. The literature has proven the significant relationship between employee and customer satisfaction, therefore, this study hypothesizes that: H2: There is a significant positive relationship between employee and customer satisfaction

\subsubsection{Word-of-Mouth}

Word-of-Mouth (WOM) has a close relation with feelings, as WOM tend to be a product of positive of negative feelings experience after engaging with the services. Similar to feelings, WOM also can be in a positive or negative form. In a positive form, consumers or passengers will tend to tell others about their good experience with the services which not only increase sales, but also reduces customer departures (Rogerson, 1983). Rogerson (1983) also mentioned that, not only will it reduce customer departures but also helps to increase sales and more customers will be excited and motivated to use the services. In terms of reputation, WOM can help spread the words to more potential customers, importantly it is for free. This is why WOM is a powerful tool for airlines to use it widely and efficiently. But in a negative way, WOM can spread like wildfire. Findings by Fisk, Brown, Cannizzaro and Naftal (1990) and Hart, Heskett and Sasser (1990) indicated that both types of consumers who experience good and bad services will tend to persuade people not to use the service or the other way round.

According to Lerrthaitrakul and Panjakajornsak (2014), to an extent there is a significant relationship between WOM and customer satisfaction that will affect consumers' decision making. These WOM are either from their trusted peers or eWOM (digital) such as forums, social media and other form of digital communication. With regards to decision making, WOM is a valuable tool for both marketers and consumers. For consumers, WOM can be used in order to evaluate services and products. While for marketer, WOM is an important mode for ensuring customer satisfaction. This is also demonstrated by Ahrens, Coyle and Strahilevitz (2013) indicated that WOM is very low cost, thus provide a powerful marketing medium for consumers during initial stage of sifting information, during post-purchase and the acceleration of acceptance and rejecting speed. Therefore, based on the literature, it is hypothesized that:

H3: There is a significant relationship between word-of-mouth (WOM) and customer satisfaction.

\subsubsection{Publicity}

Publicity is important in order to create brand awareness and promoting the company. There is a clear difference between Publicity and Advertisement, even though both may have the same function (Burnley,1998; Hennessey, 1992; and Nally 1991). Advertisement is a paid content in television, radio, newspaper, magazine, advertisement banner and so on. Publicity however, is a free content about the brand and company that appears in any media form. It can be something 
related to what others are saying about the brand, product or anything related to the company. According to Al Reis (1981) in a book he authored, "Positioning: The Battle for your Mind," he highlighted that companies should focus more on publicity rather than advertisement. This is because through publicity, they can minimize the advertisement cost while creating brand awareness and establishing credibility. Only when that particular company is established, then they can indulged further with advertisement.

The relationship between publicity and customer satisfaction are subtle but quite prominent. According to a research by Cameron (1994), publicity is much more powerful compared to advertising. It can improve customers' memory, recall, identification and purchase intention. Another finding by Kim, Kim, Park and Choi,Y (1999) also indicated that publicity is much more effective than paid advertising in many ways. However, publicity can act like a double edge sword. Publicity can be in a form of a positive or negative publicity. Negative publicity can have a major bearing on the business as a whole (Henthorne and Henthorne, 1994). LCC provider should understand this risk. They have to constantly put forward their best effort in preventing such thing from happening (Reidenbach and Sherrel, 1986). Therefore, this current study proposes the following hypothesis:

H4: There is a significant relationship between publicity and customer satisfaction

\subsubsection{Reliability}

Reliability of an airline refers to the reliability of the whole services provided. In other words, all the services attached to the company must be consistent with their claims (Qin, 2012). According to Forbes (2008), reliability level can be evaluated from cancellation flights, mishandled bags, making sure their passengers arrive on time, and making sure their operations are customer oriented. In the aviation industry, reliability can be in the form of on-time departure and arrival, no missing baggage and so on.

According to Parasuraman, Zeithaml and Berry (1988), reliability is the capability of organization to precisely achieve its services in the exact time and based upon the promises it has made to its clients. It was also stated to have a direct impact on how customer evaluates an organization as a whole including their intentions in terms of choosing the service provider (Sum Chau and Kao, 2009). Further supported by previous research, not only that reliability and customer satisfaction have a positive relationship, but also it affects greatly on customers' future purchase intentions (Lai, 2004). Reliability has become very important in the LCC industry due to an increase in flight delays and cancellations. Based on a study by the National Airlines' Passenger Bill of Rights, one out every four flights in 2006 and 2007 were either delayed or cancelled. In terms of positive correlation, reliability is said to have a positive correlation with airline profitability (Dresner and Xu, 1995).

In the low cost carrier industry, reliability issue is one of the most scrutinized issues. Reliability in low cost carrier can be in the form of on-time performance or perhaps reliable baggage handling. Reliability issues if not being taken seriously might cause passengers to perceive the carrier in a negative way. Suzuki (2000) suggests that passengers who involves in recurring delays may be more prone to switching carriers when making future travel plans. Ultimately, reliability can be divided into two attributes; airline safety perceptions and on-time performance (Mikulic and Prebezac, 2011). Therefore, knowing the important relationship of reliability and customer satisfaction, this present study proposes the following hypothesis:

\section{H5: There is a significant positive relationship between reliability and customer satisfaction.}




\subsubsection{Amenities}

Nowadays there are plenty of airline that provides low fare air transportation for travellers. The first thing a consumer will evaluate and compare would be the ticket fare whether they are offered more or less the same fare. For example, a quick check on the ticket fare for a return flight from BKI - KUL by using Air Asia will cost RM411 per person, while BKI - KUL by using Malindo Air is much cheaper at RM369 per person. The differences is a mere RM42. So what comes next after comparing prices? The answer is 'Amenities' provided on board. Amenities can be in the form of in-flight entertainment, complimentary food and seat space (leg room). Malindo Air, for example provides movies and music during flight through the seat-back screens available in their airplanes. Besides that they also provide in-flight games for children to play and to be occupied as long flight time can be excruciatingly dull. As for Air Asia, 'most' of their international flights do have in-flight entertainment as well as extra leg room for those who are willing to pay for it (malindoair.com and airasia.com).

Essentially in-flight amenities have a positive relationship with customer or passenger's satisfaction. Gilbert and Wong (2003) have shown that there is in fact an undeniably strong correlation between service provided and profit experienced from the increased of satisfaction of the service. According to Liebe (2012), the first in-flight (movie) entertainment was introduced to passengers in 1921 on board Aeromarine Airways. The management saw idle time as a source of stress for travellers, leaving an adamant bad impression about their experience while on board (Liu, 2007). Amenities are tangible in nature and past studies such as Kuo, Temponi and Corley (1996); Ismail, Ridzuan, Ranlan, Rahman and Francis (2013); and Moon (2013) hinted that amnesties have some degree of importance in terms of achieving customer satisfaction and perceived quality. Moreover, with regards to in-flight customer satisfaction, 'tangible' benefits such as amenities can help increase passengers overall satisfaction. Myant and Abraham (2007) found that in-flight entertainment does induce satisfaction as it was revealed that more passengers expressed their satisfaction over the flight entertainment provided in full-service airlines compared to those who travelled with a no-frills airline.

By improving in-flight amenities, LCC can increase their revenues as more passengers will likely to use their airlines. Revenues can be generated through offering payable in-flight amenities. Alamdari (1999) pointed out that amenities can be in a form of food and beverage services or entertainment. In today's trend, airlines are inclined on generating revenue through ancillary forms of revenue (Alamdari, 1999). By providing amenities on board, passengers are motivated to pay more and at the same time, the airline will increase their differentiation attributes. Due to the fact that passengers are willing to pay more to increase comfort on board, it reflected how flexible they are towards spending beyond what they pay for in the first place. Therefore according to Balcome, Frase and Harris (2009), low cost carriers that focus more on the in-flight service quality can create an increment in terms of profitability. Therefore, this study hypothesizes that:

H6: There is a significant positive relationship between in-flight amenities and customer satisfaction.

\subsection{Research Methodology}

The research instruments were distributed among 270 respondents who have flown with either AirAsia or Malindo Air by using a convenience sampling. The location of the study was at the Kota Kinabalu airport. Questionnaires were given to passengers that were waiting to get on board as well as those that have just arrived. The data collection was conducted over a period of two weeks. Since this study is to make a comparison of both airlines, the questionnaires were distributed equally to 135 AirAsia respondents and 135 Malindo Air passengers. The questionnaire items were adapted from Wong and Musa (2011), Qin (2012) and Namukasa (2013). All questions were written in English and Bahasa as well. The questionnaire consists of eight 
sections that cover both independent and dependent Variables. Section A (Demographic/Profile of respondents) Section B (Employees, IV), Section C (Publicities, IV), Section D (Feelings, IV), Section E (Word-of-Mouth, IV), Section F (Reliability, IV), Section G (Amenities, IV), and Section H (Customer Satisfaction, DV). The data that has been collected was analysed using the Statistic Package Social Science (SPSS) version 21.0. To predict the relationship between a Dependent Variable and multiple Independent Variables, Multiple Regression was used (Tabachnick and Fidell, 2007; Hair, Black, Babin and Anderson, 2010). For this study, multiple regressions was used to evaluate the relationship between Customer Satisfaction and the influencing Independent Variables (Publicities, Feelings, Employees, Word-of-Mouth, Reliability and Amenities.). The following is the conceptual framework of this study.

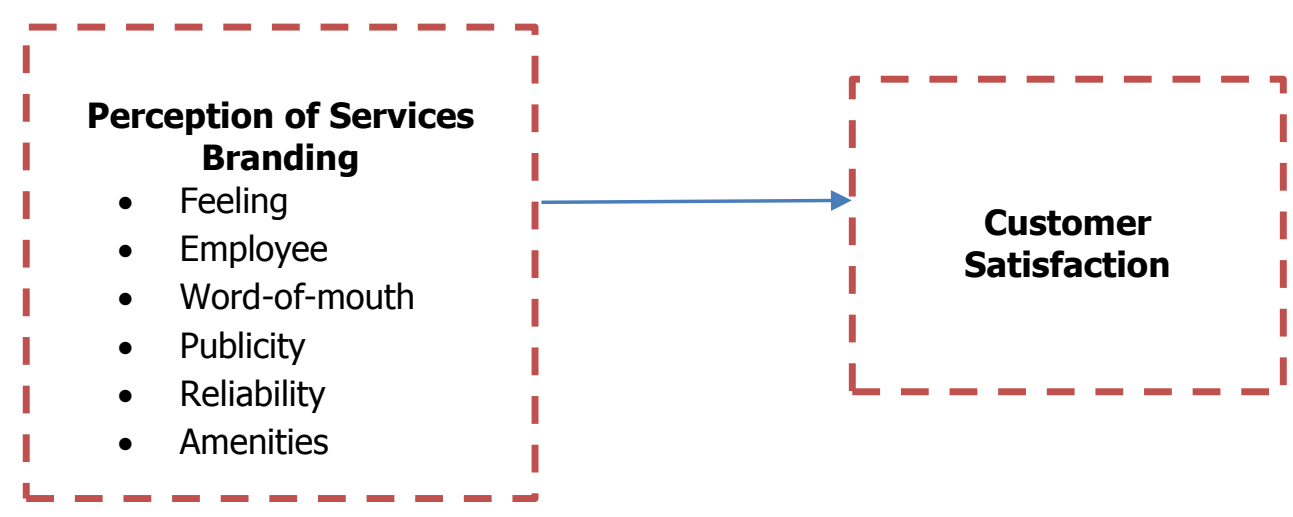

\subsection{Findings}

Table 4.1 and 4.2 represents the demographic profile for both data set. In table 4.1, it shows the demographic profile of the Air Asia's respondents while in table 4.2, it shows the demographic profile of Malindo Air's respondents. From table 4.1, more than half of the total respondents are male, which consists of 59.3 percent, followed by 40.7 percent representatives of the female gender. To conclude the projections from table 4.1, majority of the respondents are male and most of the respondents are between 25 to 45 years old, with a monthly income ranging from RM999 to more than RM3000. It is also important to take note that most of the respondents are from public and private sectors, with regards to their employment. In addition, most of them indicated that their reason to fly with the airline is for leisure and personal reason.

Table 4.1: Profile of Respondents (Air Asia)

\begin{tabular}{llcr}
\hline Variables & $\begin{array}{l}\text { Categories } \\
\text { Percentage }\end{array}$ & $\begin{array}{c}\text { Frequency } \\
(\mathbf{N}=\mathbf{1 3 5})\end{array}$ & \\
\hline $\begin{array}{llc}\text { (\%) } \\
\text { Gender }\end{array}$ & Male & 80 & 59.3 \\
& Female & 55 & 40.7 \\
\hline \multirow{2}{*}{ Age } & Less than 25 & 17 & 12.6 \\
& $25-35$ & 34 & 25.2 \\
& $36-45$ & 35 & 25.9 \\
& $46-55$ & 24 & 18.5 \\
& 56 or older & & 17.8 \\
& & 21 & 6.7 \\
Employment & Self-employed & 9 &
\end{tabular}




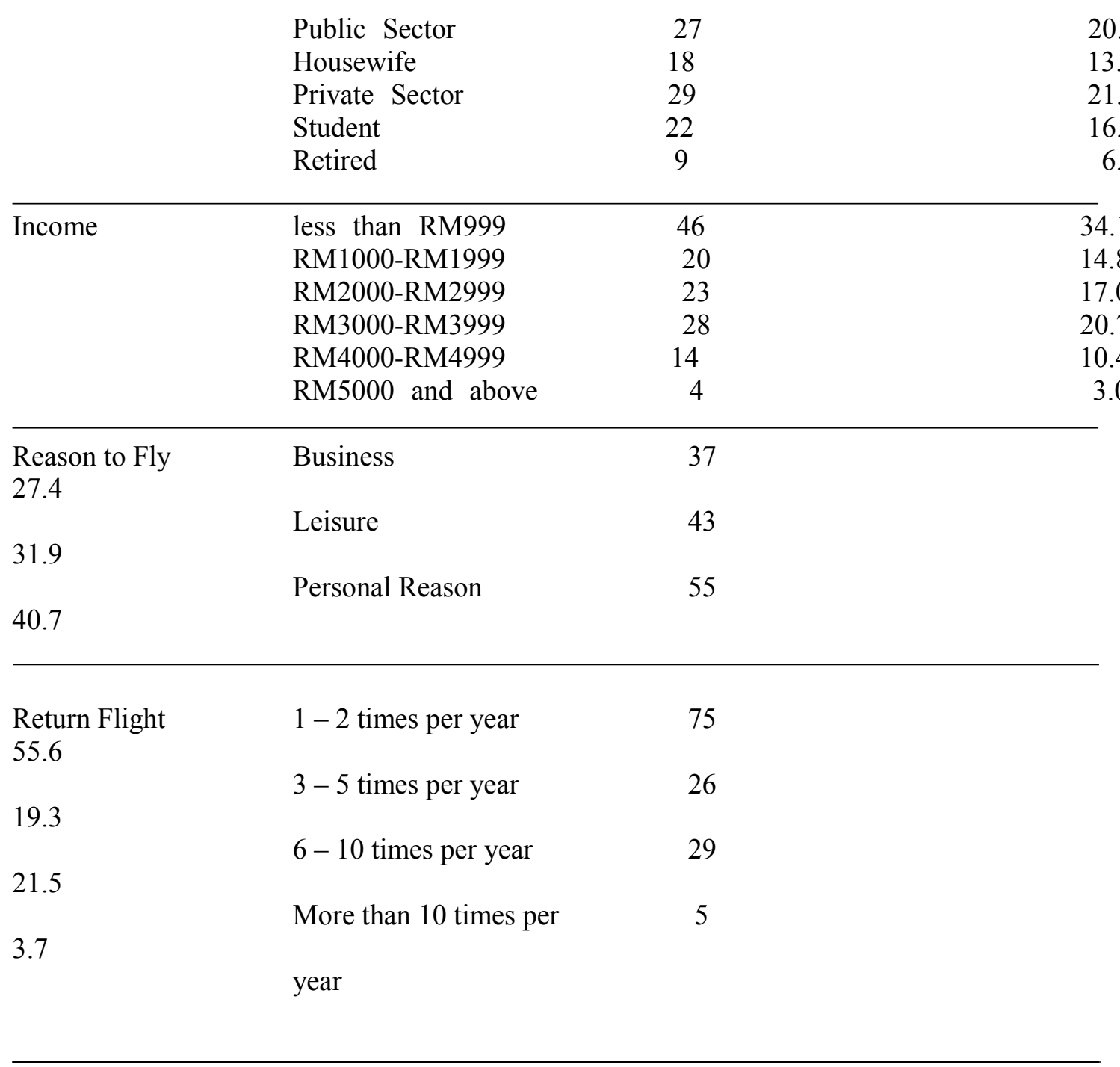

Table 4.2 representing Marlindo Airlines respondents. It is found the male population is the majority with 57 percent followed by female respondents with 43 percent. The majority of the respondent for Malindo Air came from the age range of between 25 to 35 years old that represents 30.4 percent, followed by those from the age range of 36 to 45 years old with 27.4 percent. In terms of employment, most of the respondents worked in the Public Sector which comprises of 28.1 percent, followed by those indicated Private Sector with 27.4 percent. It was also found that most of the respondents indicated their reason to travel or fly is due to Personal Reason with 41.5 percent, followed by Leisure with 37 percent and Business with 21.5 percent. Moreover, Majority of them indicated 1 to 2 times per year of return flight which represents 48.9 percent, followed by 3 to 5 times per year with 26.7 percent. There are 22.2 percent who indicated 6 to 10 times per year which represents 22.2 percent while there is only 2.2 percent who indicated of more than 10 times per year. 
Table 4.2: Profile of Respondents (Malindo Air)

\begin{tabular}{|c|c|c|c|}
\hline Variables & $\begin{array}{l}\text { Categories } \\
\text { Percentage }\end{array}$ & $\begin{array}{l}\text { Frequency } \\
(\mathrm{N}=135)\end{array}$ & $(\%)$ \\
\hline \multirow[t]{2}{*}{ Gender } & Male & 77 & 57.0 \\
\hline & Female & 58 & 43.0 \\
\hline \multirow[t]{5}{*}{ Age } & Less than 25 & 13 & 9.6 \\
\hline & $25-35$ & 41 & 30.2 \\
\hline & $36-45$ & 37 & 27.4 \\
\hline & $46-55$ & 35 & 25.9 \\
\hline & 56 or older & 9 & 6.7 \\
\hline \multirow[t]{7}{*}{ Employment } & Self-employed & 27 & 15.6 \\
\hline & Unemployed & 1 & 6.7 \\
\hline & Public Sector & 38 & 20.0 \\
\hline & Housewife & 7 & 13.3 \\
\hline & Private Sector & 37 & 21.5 \\
\hline & Student & 15 & 16.3 \\
\hline & Retired & 10 & 7.4 \\
\hline \multirow[t]{6}{*}{ Income } & less than RM999 & 16 & 11.9 \\
\hline & RM1000-RM1999 & 23 & 17.0 \\
\hline & RM2000-RM2999 & 46 & 34.1 \\
\hline & RM3000-RM3999 & 40 & 29.6 \\
\hline & RM4000-RM4999 & 8 & 5.9 \\
\hline & RM5000 and above & 2 & 1.5 \\
\hline \multirow{2}{*}{$\begin{array}{c}\text { Reason to Fly } \\
21.5\end{array}$} & Business & 29 & \\
\hline & Leisure & 50 & \\
\hline & Personal Reason & 56 & \\
\hline 41.5 & & & \\
\hline \multirow{2}{*}{$\begin{array}{l}\text { Return Flight } \\
48.9\end{array}$} & $1-2$ times per year & 66 & \\
\hline & $3-5$ times per year & 36 & \\
\hline 26.7 & $6-10$ times per year & 30 & \\
\hline 22.2 & $\begin{array}{l}\text { More than } 10 \text { times per } \\
\text { Year }\end{array}$ & 2.2 & \\
\hline
\end{tabular}

\subsection{Factor Analysis}

Data reduction is used to reduce a large number of variables to a smaller set of underlying factors that summarizes the essential information contained in the variables. The Kaiser-MeyerOlkin or KMO measure of Sampling Adequacy values must exceed .50 (Neuman, 2003; Tabachnick and Fidell, 2008). Initially, there were 33 measurement items in this study which was 
adapted from Wong and Musa (2011), Khatib (1998), Chung and Shin (2010), Qin (2012), Taylor and Claxton (1994), Tolpa (2012), Namukasa (2013), and Archana and Subha (2012). After the sixth run on the factor analysis which all cross-loaded items were removed, only 19 items left in a perfect harmony. Based on table 4.3 below, the Bartlett's Test of Sphericity is significant (ChiSquare $=2560.735, \mathrm{p}<0.01$ ), while the KMO measures at 0.737 which indicates sufficient intercorrelations. Table 4.3 highlights all the 19 items which produced six factor loadings.

Table 4.1: Factor Analysis of Independent Variables

\section{No Item}

\section{Factor 1: Amenities}

1. The seats are very comfortable. (.941)

2. The personal entertainment appliances (audio, video, and games) are available and functioning. (.937)

3. My in-flight experience with this airline has exceeded my expectations. (.902)

4. Considering the in-flight services that this airline offers; they are worth what I pay for. (.706)

\section{Factor 2: Word-of-Mouth}

1. My attitudes towards the airline are easily influenced by word-of-mouth (.902)

2. I would recommend this airline to anyone who seeks my advice. (.842)

3. My evaluations towards the airline are easily influenced by word-of mouth. (.787)

\section{Factor 3: Reliability}

1. In case of delay, ariline immediately makes an announcement and provides necessary information (length of waiting, possibility to receive food vouchers, stay at the hotel, or rebook a flight.) (.842)

2. The airline has other travel-related partners such as car rentals, hotels and insurance where you can get discounts or earn extra miles. (.778)

3. Bag checks are fast. (.667)

4. There are remedies for delayed or missing baggage. (.602)

\section{Factor 4: Feelings}

1. The airline provides a high security air transportation experience. (.871)

2. I think I will have a safe journey while traveling with this airline. (.824)

3. The airline provides warmth air transportation experience. (.812)

\section{Factor 5: Publicity}

1. My attitude towards airline is influenced by their publicities. (.841)

2. My evaluation of airline is easily influenced by their publicities. (.793)

3. The airline has informative publicities. (.777)

\section{Factor 6: Employee}

1. The airline has courteous employees. (.879)

2. The airline has friendly employees. (.858) 
Meanwhile, for dependent variable namely customer satisfaction, the KMO value is .640 with eigenvalue of 2.061, which is considered as an adequate measure of sampling. The Bartlett's Test of Sphericity emulates significance as the test of Chi-Square is 236.569 with .000 significant. The process only took 1 round to complete. In table 4.4 the result of the factor analysis for the dependent variable is shown.

Table 4.4: Result of Factor Analysis (DV)

\begin{tabular}{llc}
\hline \multicolumn{1}{c}{ Items } & Factor \\
\hline & $\mathbf{1}$ \\
1. I made the right choice by using the airline. & .893 \\
2. I had a good experience with the airline. & .810 \\
3. I am satisfied with my decision to choose this airline. & .780 \\
& $\mathbf{2 . 0 6 1}$ \\
Initial Eigenvalue & $\mathbf{6 8 . 7 1 3}$ \\
\hline
\end{tabular}

\subsection{Reliability of Measure}

Reliability analysis was performed to conclude whether a group of items (generated from Factor Analysis with adequate loadings) can consistently reflect the construct it is measuring. The Cronbach's Alpha coefficient can range from 0.0 to 1.0. The closer the coefficient is to 1.0 , the better it is, as it is considered as having a high internal consistency. According to Sekaran (2003), less than 0.6 is considered to be poor, 0.7 is acceptable and 0.8 and above is considered as good.

Table 4.5: The Reliability Analysis

\begin{tabular}{llcc}
\hline No & Variable & No. of Items & Cronbach's Alpha \\
\hline 1 & Amenities & 4 & .905 \\
2 & WOM & 3 & .823 \\
3 & Reliability & 4 & .718 \\
4 & Feelings & 3 & .792 \\
5 & Publicity & 3 & .745 \\
6 & Employee & 2 & .714 \\
\hline
\end{tabular}

Based on table 4.5, the chronbach's alpha for the variables listed above ranges from 0.714 to 0.905. None of the Chronbach's Alpha have values below .70. In line with Pallant (2007), the chronbach's alpha should be above 0.70 as to be used in a study. For this study, Amenities have the highest Chronbach's Alpha value with 0.905 while Word-of-Mouth is the second highest with 0.823 .

\subsection{Correlation Analysis}

According to Pallant (2007), the Pearson correlation coefficients are used in order to examine the strength and the direction of the relationship between all the constructs in this present study. The values of the correlation coefficient can fluctuate from -1.00 to +1.00 . Since the correlation ranges from .172 to .476 , Cohen (1988) suggests that the correlations are both between 'small' and 'medium'. 
Table 4.6: Pearson Correlation Matrix of the Variables

\begin{tabular}{llrrrrrrr}
\hline Variables & 1 & 2 & 3 & 4 & 5 & 6 & 7 \\
\hline 1 & Amenities & 1 & & & & & & \\
2 & WOM & $.154^{*}$ & 1 & & & & & \\
3 & Reliability & $.133^{*}$ & $.347^{* *}$ & 1 & & & & \\
4 & Feelings & $.129^{*}$ & $.229^{* *}$ & $.303^{* *}$ & 1 & & & \\
5 & Publicity & $.380^{* *}$ & $.124^{*}$ & $.132^{*}$ & $.240^{* *}$ & 1 & & \\
6 & Employee & $.166^{* *}$ & $.302^{* *}$ & $.261^{* *}$ & $.202^{* *}$ & $.193^{* *}$ & 1 & \\
7 & CS & $.476^{* *}$ & $.271^{* *}$ & $.200^{* *}$ & $.172^{* *}$ & $.270^{* *}$ & $.281^{* *}$ & 1 \\
\hline
\end{tabular}

* Correlation is significant at the 0.05 level (2-tailed)

**Correlation is significant at the 0.01 level (2-tailed)

\subsection{Multiple Regressions}

Multiple regressions was used to evaluate the relationship between Customer Satisfaction (Dependent Variable) and Amenities, Word-of-Mouth or WOM, Reliability, Feeling, Publicity, and Employee (Independent Variables). It is found that the $\mathrm{R}^{2}$ is 54.7 percent of variance is described by five independent variables. In terms of Adjusted $\mathrm{R}^{2}$, the value is 28.3 percent. The $\mathrm{F}$ Value which signifies the overall significance of Independent Variables stood at 18.7 percent. Importantly, it was found that there are three variables that have significant relationship with customer satisfaction when their $\mathrm{p}$ value is significant and less than .05 , which are Amenities ( $\mathrm{p}$ value=.000), WOM ( $\mathrm{p}$ value=.020), and Employee ( $\mathrm{p}$ value=.007). Meanwhile, the other three variables namely reliability, feelings and publicity could not be supported due to their $\mathrm{p}$ values which are greater than 0.05 .

Table 4.11: Multiple Regressions on Customer Satisfaction

Variables Dependent Variable (Customer Satisfaction)

Standard Beta

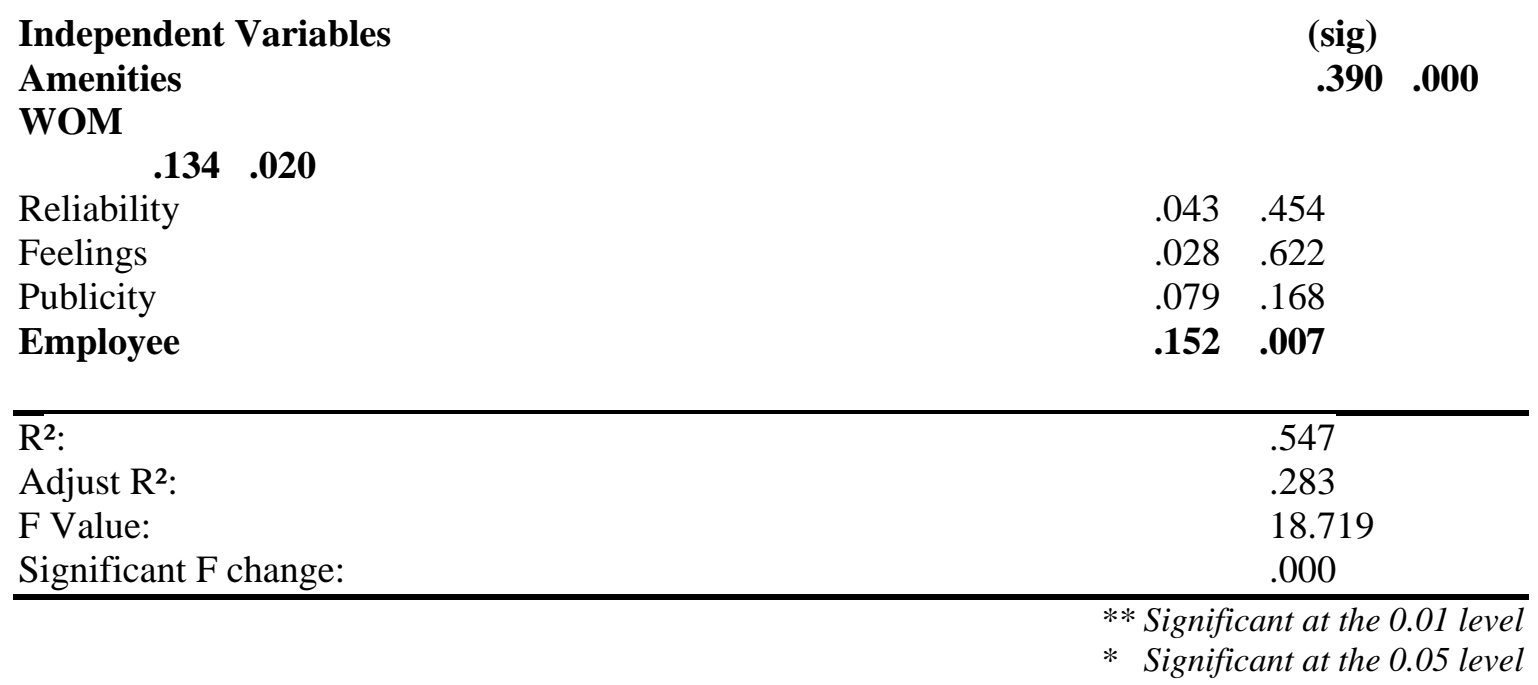

\subsection{Findings}

\subsection{The Relationship between Feelings and Customer Satisfaction}

Based on the regressions analysis, finding reveals that the relationship between feelings and customer satisfaction is not significant as $\mathrm{p}=.622$ with $\beta=.028$, thus Hypothesis H1 could 
not be supported. Interestingly, this present finding is contradicted with many of previous findings which supported the fact that feelings have a positive and significant relationship with customer satisfaction (Arnould and Price, 1993; Westbrook and Oliver, 1991), and feelings was highlighted as important indicator in explaining customer satisfaction especially in service industry. In addition, Wen and Yeh (2010) also stressed the importance of feelings in airline industry; they further explained that constant assurance on the safety of flight is a must after the September 11 incident. Similarly, feelings was also mentioned as the most important factor in choosing an airline (Atalik and Arslan, 2009; Clemes, Gan, Kao and Choong., 2008; Nejati, Nejati and Shafaei, 2009; Wan and Hui, 2005; Wen and Yeh, 2010). Even though a lot of previous studies supported the relationship between feelings and customer satisfaction, this study did not manage to get the same result. This is probably due to the different settings and approach of this present study, or perhaps, passengers of both airlines found it the least to think about.

\subsection{The Relationship between Employee and Customer Satisfaction}

The result from multiple regressions between employee and customer satisfaction is significant as value of $p=.007$ and $\beta=.152$ thus hypothesis $\mathrm{H} 2$ is supported. An article wrote by Boone and Kurtz (2009) stated the level of customer satisfaction reveals the employees performances. In airline industry, employees' performances are expected to be superior. Suhartanto and Noor (2012) stated employee plays a very important role in low cost airline. It goes on to explain that the key to gain customer satisfaction is through the employee ability to be willing to help, to give attention, and to create consumer confidence in the airline industry. It is a factor that can determine the comfort of the flight as a whole.

In terms of employee and customer satisfaction with regards to Air Asia, this brand is very much well known to have master this practice since their first year of operation. All of their staffs from pilots to ground staffs are used to multi-tasking, Air Asia pilots are for example certified with Directorate General of Civil Aviation to carry out technical checks and cabin crew are always helping the ticketing staff (rediff.com, 2014). This is a very good example of creating consumer confidence in terms of safety and ultimately satisfaction. On a negative side of this perspective, recent case of strike by Malindo Air's baggage handlers in Kuala Lumpur International Airport (KLIA) has caused a stir in the airport as the baggage handlers refused to unload luggage from a Malindo Air flight from New Delhi. This event has caused a great distress among many passengers and they have put the blame of this unwanted event to the management. Hence, depending on the situation, either in a negative or positive manner, abviously customer satisfaction can be affected by key factor such as employee.

\subsection{The Relationship between Word-of-Mouth (WOM) and Customer Satisfaction.}

Word-of-Mouth (WOM) is a very interesting variable as it is somehow our nature to inform and be informed, and has been studied by many marketing researchers (eg: Bolton and Drew, 1992; Holmes and Lett, 1977; Reichheld and Sasser, 1990; Schlesinger and Heskett 1991; Swan and Oliver, 1989). An interesting research question or dilemma has been quoted long ago by E.W Anderson (1998); "Do dissatisfied customers engage in more or less word-of-mouth than satisfied customers?" Word-of-Mouth in general refers to unceremonious communication between parties with regards to evaluating something like products or services (Dichter, 1966; Fornell and Bookstein, 1982; Singh, 1988; Westbrook and Oliver, 1987), a total opposite to the nature of direct complaining to firms or personnel. WOM can be pleasant, positive, neutral interesting, can be in the form of information, but also it can be hurtful, bashful, negative, degrading, and unpleasant, and can spread like wildfire.

Significantly, for a positive WOM, this present study has demonstrated a positive relationship with customer satisfaction. According to Dichter (1966) and Arndt (1967), 
theoretically positive WOM can be in the form of (a) Altruism (the desire to help), (b) Instrumentalism (desire to appear well informed), (c) Ego defense and (d) reduction of cognitive dissonance. As for a negative WOM, the same researchers established some grounds saying unsatisfied customer tend not to transmit bad news or information when they want to avoid the feeling of guilt. But Westbrook and Oliver (1987) managed to come up with findings which suggested dissatisfied customers tend to provide bad WOM. But in today's business environment as technological advancement such as the internet became the main medium, it is safe to say that either perspective or findings is right. Unhappy customer tends to share their thoughts on social media and so is those who are happy with the same services. With the internet technology taking the central attention, numerous websites reviewing airlines services can be found. These websites also gather or store people experiences by allowing them to comments on their webpage. So these kinds of WOM can be in a negative form or positive form, and it can be accessed across the world. So imagine, prior to booking of a flight ticket, a passengers has already know what to expect from the airline provider. In conclusion, it is important to understand the significant influence of WOM on customer satisfaction.

\subsection{The Relationship between Publicity and Customer Satisfaction}

Surprisingly, the result of regressions analysis revealed publicity has no relationship with customer satisfaction when the $p$ value is greater than $0.05(p=.168 ; \beta=.079)$ and therefore, it did not support the Hypothesis H4. The finding of the present study is not in line with many previous studies which found publicity has a strong relationship with customer satisfaction (Luo and Homburg, 2007). The study of Luo and Homburg (2007) explained that customer satisfaction, if achieved, would have saved subsequent marketing costs as publicity rose to do the marketing effort for the company. In addition, Seiders, Voss, Grewal and Godfrey (2005) indicated publicity has a relationship with customer satisfaction.

Importantly, this present study however revealed that there is no positive relationship between publicity and customer satisfaction. It can be inferred that low cost airlines' passengers might have the perception that publicity is not important element to contribute to their satisfaction with the brands. The publicity efforts of the both airline brands are not what they receive and experience directly, which they can feel and evaluate. Significantly, they rather satisfied of services provided by both airlines which they can experience and feel such as amnesties on board or exceptional hospitality delivered by their great employees.

\subsection{The Relationship between Reliability and Customer Satisfaction}

The regression's result indicated that the value of $p=.454$ with beta $\beta=.043$ clearly indicating the relationship is insignificant between reliability and customer satisfaction. Hence H5 was not supported. Based on this result, it can be concluded that reliability is not an important factor influencing low cost airlines customers in Malaysian context. Contrary to many of previous studies, reliability can be seen as the ability to perform the promised service dependably and accurately, and is considered as important compared to other variables (Yunus, Bojei and Wan Rashid, 2013). The same study also emphasized on on-time departures and delay management. But somehow this study did not see the significances of reliability and the relationship it has with customer satisfaction.

Other study also indicated reliability as a definite variable that is highly related to the attainment of customer satisfaction (Qin, 2012), elaborating that reliability is essential in the survivability of a low cost airline. A reliability issue in low cost airline has been seen as the pinnacle of scrutiny by customers. Ariffin, Salleh, Aziz and Asbudin (2010) in their study also indicated reliability as the second most important components of service brands in low cost airline after 'Caring and Tangible'. Although there are plenty more studies revealing the positive relationship between reliability and customer satisfaction, this study somehow does not support 
that notion. It can be assumed that passengers here have a very limited choice of low cost airline. With that in mind, passengers here have high tolerances towards reliability issues. Besides that, pricing can also play an important indicator for this finding. Due to the fact that low cost airline offers cheap tickets to fly, passengers in this study's context tend to negate reliability issues.

\subsection{The Relationship between Amenities and Customer Satisfaction.}

Hypothesis H6, which is to examine whether if there is a significant relationship between amenities and customer satisfaction, has been proven that the relationship is significant between amenities and customer satisfaction. In a study on customer satisfaction determinants in railway platforms (Nandan, 2010), amenities have been identified as one of the key determinants in ensuring customer satisfaction. Although the research of Nandan has a different setting than this present study (in the context of low cost airline), findings of this study managed to point out the fact that amenities is a dynamic determinant and a common expectation among low cost airlines customers or passengers. For example, refreshment which is important item of amenities is in fact having multiple dimensions such as the availability, quality, quantity and affordability. Importantly, amenities remains as the most important aspects of customer satisfaction in the low cost airlines.

Evidently, both Malindo Air and Air Asia provide amenities on-board. Their on-board amenities ranging from refreshments to electronic devices such as personal screen or monitor. But between those two low cost airlines, only Malindo Air provides complimentary (i.e. benefit) food and non-alcohol beverages. Even though study found most of the respondents agreed that the food has average quality, it does somehow provides a good impression by being able to provide customers something for free (Malindo Air was rated 5/5 star by airlineratings.com in 2013 and listed amenities both in Economy and Business Class as key determinants.) As for Air Asia, even though they do not provide hefty amenities on-board, at least the airline tries to adapt to these changes by instilling tactics such as, any pre-book up to two meals online will be automatically discounted and some of the overseas flights provide electronic entertainment appliances for passengers (but not that many flights have them, and it is not free).

\subsection{Conclusion}

This research aims to shed some light on service brands components that affects customer satisfaction in low cost airline industry of the brands namely Air Asia and Malindo Air. Based on this present findings, it was found that there are three key factors that can affect customer satisfaction of low cost airlines, which are amenities, word-of-mouth and employee. On the other hand, the other three independent variables namely publicity, reliability and feelings were found to have insignificant relationships with customer satisfaction. Therefore, marketers of low cost airlines have to amplify their in-flight services, pay great attention to consumer reviews in social media, and continue training and upgrading their employees' skills to enhance their service branding. In return, this efforts hopefully will ease their endeavour to best serve their customers through service branding efforts which in the long run will help them to sustain and expand their business to another level. 


\section{References}

Adsit,D.J., London,M., Crom,S. Jones,D.(1996),"Relationships Between Employee Attitudes, Customer Satisfaction And Departmental Performance", Journal of Management Development, Vol. 15 Issue: 1, pp.62-75

Ahrens, J., Coyle, J., \& Strahilevitz, M. (2013). "Electronic Word Of Mouth: The Effects Of Incentives On E-Referrals By Senders And Receivers", European Journal of Marketing, 47(7), pp.1034-1051

Alamdari, F., (2009), “Airline In-Flight Entertainment: The Passengers' Perspective.”, Journal Of Air Transport Management, 5(4),pp. 203-209.

Anderson, E.W.,(1998),’Customer Satisfaction and Word of Mouth”, Journal of Service Research, Vol.1, No.1,pp.5-17

Archana,R. Subha,M.V., (2012), “A Study On Service Quality And Passenger Satisfaction On Indian Airlines.”,International Journal Of Multidisciplinary Research, Vol.2 Issue 2,pp.50-63

Ariffin A.A, Salleh, A.H.M, Aziz, N.A, and Asbudin, A.A., (2010), "Service Quality And Satisfaction For Low Cost Carriers", International Review of Business Research Papers 6(1): 47-56

Arndt,J. (1967), "The Role of Product-Related Conversation in the Diffusion of a New Product", Journal of Marketing Research, 4 (August), pp.291-295

Arnould, E.J and Price,L. (1993) River magic: extraordinary experience and the extended service experience. Journal of Consumer Research 20(1),pp.24-45

Atalik, O., Arslan, M. (2009),"Customer Value Analysis From A Customer's Perspective: Case Of Turkish Airlines Domestic Passengers", International Business Research, 2(3), pp.85-91.

Balcombe, K., Fraser, I., And Harris, L.( 2009) "Consumer Willingness To Pay For In- Flight Service And Comfort Levels: A Choice Experiement.”, Journal Of Air Transport Management, 15(5), pp.221-226.

Bolton, R.N. and Drew, J.H., (1992), "Mitigating the Effect of Service Encounters", Marketing Letters, 3(1),pp.57-70

Boone, L.E. \& Kurtz, D.L. (2007). Contemporary marketing. New York: Harcourt Brace College Publishers.

Burnley,R. (1998), "International Publicity: Concepts And Applications", Marketing Intelligence \& Planning, Vol. 16 Issue: 2, pp.107-113

Cameron, G. (1994), "Does Publicity Outperform Advertising?: An Experimental Test Of The Third Party Endorsement",Journal of Public Relation. Res., 6(3), pp. 185-207

Chung,K.H., Shin,J.I., (2010) "The Antecedents And Consequents Of Relationship Quality In Internet Shopping", Asia Pacific Journal Of Marketing And Logistics, Vol. 22 Issue: 4, pp.473-491

Clemes, M.D, Gan,C.E.C., Kao, T.H., Choong, M. 2008. (2008),”An Empirical Analysis Of Customer Satisfaction In International Air Travel", Innovative Marketing, 4: p.p 49-62.

Cohen, J. (1988),"Set correlation and contingency tables", Applied Psychological Measurement, 12, pp. $425-434$.

Dichter, E.(1966), “How Word-of-Mouth Advertising Works”, Harvard Business Review, 16(NovemberDecember), pp.147-166

Dresner, M.,Xu, K., (1995), "Customer Service, Customer Satisfaction, And Corporate Performance In The Service Sector.” Journal Of Business Logistics 16(1),pp. 23-40

Farris, P.W., Bendle, N.T., Pfeifer,P.E., Reibstein,D.J.,( 2010), "Marketing Metrics: The Definitive Guide To Measuring Marketing Performance", $\quad$ Upper Saddle River, New Jersey: Pearson Education, Inc.

Fisk, T.A., Brown, C.J., Cannizzaro, K.G., Naftal, B. (1990), “Creating Patient Satisfaction And Loyalty”, Journal of Health Care Marketing, Vol. 10 No. 2, June, pp. 5-15.

Forbes, S. J. (2008), 'The Effect Of Air Traffic Delays On Airline Prices", International Journal Of Industrial Organization, 26(5), pp.1218-1232.

Fornell, C. and Bookstein, F.L., (1982), "Two Structural Equation Models : LISREL and PLS Applied to Exit-Voice Theory", Journal of Marketing Research, 19(November), pp.440-452

Gilbert, D.,Wong, R. K. (2003), "Passenger Expectations And Airline Services: A Hong Based Study." Tourism Management, 24(5), pp.519-532.

Gour C., Theingi,S.,(2009),"Service Quality, Satisfaction, And Behavioural Intentions: A Study Of Low-Cost Airline Carriers In Thailand", Managing Service Quality, Vol. 19 Iss: 3, pp.350 - 372

Grönroos, C. (1994), From Marketing Mix To Relationship Marketing: Towards a paradigm shift in marketing. Australasian Marketing Journal, 2(1), pp.9-29.

Hair, J. F., Black, W. C., Babin, B. J., \& Anderson, R. E. (2010), “Multivariate Data Analysis (7th ed.)”. NewJersey: Pearson Prentice Hall 
Hart, W.L., Heskett, J.L. and Sasser, W.E. Jr (1990), “The Profitable Art Of Service Recovery”, Harvard Business Review, July-August, pp. 148-56.

Hennessey, H. (1992), "Global Marketing Strategies", 2nd ed., Houghton Mifflin, Boston, MA. Henthorne,B.H, Henthorne,T.L.,(1994) "The Tarnished Image: Anticipating and Minimizing the Impact of Negative Publicity in Health Services Organizations", Journal of Consumer Marketing, Vol. 11 Issue: 3, pp.44-54

Holmes, J.H.,Lett, J.D,(1977),"Product Sampling and Word of Mouth”, Journal of Advertising Research, 17(5), pp.35-40

Iaffaldano, M. T., Muchinsky, P. M.,(1985), "Job Satisfaction And Job Performance: A Meta-Analysis.”, Psychological Bulletin, Vol. 97, pp. 251-73

Ismail, A., Ridzuan, A. A., Ranlan, N.I., Bin, M.M., Rahman, M.S. \& Francis, S. K. (2013),'Examining the Relationship Between Service Quality and Customer Satisfaction: A Factor Specific Approach", Journal of Industrial Engineering and Management, 6.2, 654.

Jensen, R.L.,(2009), "A Process Perspective on the Passenger Market in Copenhagen Airport", Master Thesis, Copenhagen Business School

Jorre, A. (2013) ,'Low Cost Airlines: A Constantly Evolving Model', http://www.amadeus.com/blog/13/09/low-costairlines-a-constantly-evolving-model/

Khatib, F. S. (1998), "An Investigation of Airline Service Quality, Passenger Satisfaction and Loyalty: The Case of Royal Jordanian Airline", Doctor of Philosophy Thesis, Sheffield University Management School, Sheffield University.

Kim,Y., Kim,J. ,Park,J.,Choi,Y.,(1999) "Evaluating Media Exposure: An Application Of Advertising Methods To Publicity Measurement", Corporate Communications: An International Journal, Vol. 4 Issue: 2, pp.98-105,

Kuo, Y.F., Temponi, C., Corley, H.W. ,(1996), “Customer Satisfaction Assessment Through A Fuzzy Neural Controller", ISAI/IFIS 1996, Mexico-USA Collaboration in Intelligent Systems Technologies. Proceedings

Lai, T. L. (2004), "Service Quality And Perceived Value's Impact On Satisfaction Intention And Usage Of Short Message Service (SMS)." International System Frontiers, 6(4),pp.353-368.

Larreche, A., (1998), "Markstrat 3: "The Strategic Marketing Simulation.", South-Western College Publishing.

Lerrthaitrakul,W.,Panjakajornsak,V.,(2014), “The Impact Of Electronic Word-Of-Mouth Factors On Consumers' Buying Decision-Making Processes In The Low Cost Carriers: A Conceptual Framework", International Journal Of Trade, Economics And Finance, Vol. 5, No. 2,Pp.142-146

Liebe, J. (2012), "The Evolution of In-Flight Entertainment", Retrieved from http://airfax.com/blog/index.php/2012/09/04/speakers-corner-theevolution-of-in-flightentertainment/

Liu, H.,(2007), "In-Flight Entertainment System: State Of The Art And Research Directions." Second International Workshop on Semantic Media Adaptation and Personalization ,pp.241-244.

Luo, X., \& Homburg, C. (2007), "Neglected Outcomes Of Customer Satisfaction", Journal of Marketing, 71(2), pp.133-149

Mathieu, J. E., Zajac, D. M.,(1990), "A Review And Meta-Analysis Of The Antecedents, Correlates, And Consequences Of Organizational Commitment.” Psychological Bulletin. Vol. 108, pp. 171-94

Mikulić,J., Prebežac, D.,(2011) "What Drives Passenger Loyalty To Traditional And Low-Cost Airlines? Formative Partial Least Squares Approach", Journal of Air Transport Management, Volume 17, Issue 4, pp. 237-240

Moon, Y. J. (2013),'The Tangibility And Intangibility Of E-Service Quality",International Journal of Smart Home, 7(5), pp.91-102.

Morrison, S.A.,Winston,C.,(1996), “Causes And Consequences Of Airline Fare Wars.”, Brookings Papers on Economic Activity

Muhammad,T.J, Kalthom,A., Ali,S.(2013), "The Impact of Customer Satisfaction on Word-of-Mouth: Conventional Banks of Malaysia Investigated ", International Journal of Information Technology \& Computer Science ( IJITCS ) (ISSN No : 2091-1610)Volume 10 : Issue No : 3 : Issue on : July / August, 2013

Muhannad M.A Abdallat, Hesham El -Sayed El - Emam(2008), "Customer Satisfaction.”,Journal Of King Saud University, Vol. 17, Tourism And Archaelogy (2), pp. 45-60

Myant, P., \& Abraham, R. (2009). Research on the air-passenger experience at Heathrow, Gatwick, Standsted and Manchester airports. In O. International (Ed.), (pp. 1-53). London. 
Nally, M. (1991, "International Public Relations in Practice”, Kogan Page, London.

Namukasa,J.,(2013), "The Influence Of Airline Service Quality On Passenger Satisfaction And Loyalty: The Case Of Uganda Airline Industry", The TQM Journal, Vol. 25 Iss: 5, pp.520 - 532

Nandan,G.S.,( 2010), "Determinants Of Customer Satisfaction On Service Quality: A Study Of Railway Platforms In India", Journal of Public Transportation, Vol. 13, No. 1,pp.97-113

Nejati, M., Nejati, M., \& Shafaei, A. (2009), "Ranking Airlines' Service Quality Factors Using A Fuzzy Approach: Study Of The Iranian Society", International Journal of Quality \& Reliability Management, 26(3), p.p 247-260

Neuman, W. L. (2003), "Social Research Methods: Qualitative And Quantitative Approaches" (5th ed.), Allyn and Bacon,Boston

O'Connell, J.F., Williams,G.,(2005)," Passengers' Perceptions Of Low Cost Airlines And Full Service Carriers: A Case Study Involving Ryanair, Aer Lingus, Air Asia And Malaysia Airlines", Journal Of Air Transport Management, Volume 11, Issue 4, pp. 259-272.

Pallant, J. (2007). SPSS survival manual: A step by step guide to data analysis, 3rd Ed., Open University Press, Berkshire, U.K

Parasuraman,A.,Zeithaml,V.A and Berry,L.L. (1988), "Servqual: A Multiple-Item Scale For Measuring Consumer Perceptions Of Service Quality,” Journal Of Retailing, Vol. 64, No. 1, p.p 12-40, 1988.

Price, L.L., Amould, J.E., Deibler, L. S. (1995). Customers' Emotional Responses to Service Encounters: The Influence of The Service Provider. International Journal of Service Industry Management, 6(3), pp.34-63.

Qin, Z. (2012),"The Factors Influencing Low-cost Airline Passenger Satisfaction and Loyalty in Bangkok, Thailand", (Doctoral Dissertation, University of the Thai Chamber of Commerce).

Reichheld, F.F and Sasser, W.E.,(1990), "Zero Defections : Quality Comes to Services”, Harvard Business Revies, 68(September-October), pp.105-111

Reidenbach, R.E. and Sherrell, D.L. (1986), "Negative Press: Is Your Company Ready?", Business, January, Vol. 36 No. 1, pp. 3- 10

Ries,A., Trout, J. (1981), "Positioning: The battle for your mind”, McGrawHill, New York

Rogerson, W.P.,(1983), "Reputation And Product Quality", The Bell Journal of Economics 2, pp.508-516

Saha, G. C., \& Theingi, (2009),"Service Quality, Satisfaction, And Behavioural Intentions: A Study Of Low-Cost Airline Carriers In Thailand", Managing Service Quality: An International Journal, 19(3), pp.350-372.

Schlesinger, L.A and Heskett, J.L.(1991), "The Service-Driven Service Company", Harvard Business Review, 69(September-October), pp.71-81

Seiders, K.,Voss,G.,Grewal,D. and Godfrey,A. (2005), "Do Satisfied Customers Buy More? Examining Moderating Influences in a Retailing Context," Journal of Marketing, 69 (October), pp.26-43

Sekaran, U., (2003),"Research Methods for Business: A Skill e Building Approach", $4^{\text {th }}$ ed., John Willey \& Son, Inc, New York

Shostack G.L, (1997),"Breaking Free From Product Marketing”, Journal of Marketing, Vol. 41(2), pp.73-80. Singh,J.(1988),"Consumer Complaint Intentions and Behaviour : A Review and Prospect", Journal of Marketing,52(January), pp.93-107

Sorensen T.C. (2005), “An Analysis Of The European Low Fare Airline Industry With Focus On Ryanair”, Master's Thesis, Aarhus School of Business, Denmark

Suhartanto, D. and Noor, A.A., (2012), "Customer Satisfaction In The Airline Industry: The Role Of Service Quality And Price", Asia Tourism Forum Conference 2012.

Sum Chau,V. Kao,Y.Y., (2009) "Bridge Over Troubled Water Or Long And Winding Road?: Gap- 5 In Airline Service Quality Performance Measures", Managing Service Quality: An International Journal, Vol. 19 Issue: 1, pp.106-134

Suzuki, Y. ,(2000), "The Relationship Between On-Time Performance And Airline Market Share." Transportation Research: Part E”,Logistics And Transportation Review, 36(2),pp. 139-154.

Swan, J.E and Oliver, R.L., (1989),"Postpurchase Communications by Consumers", Journal of Retailing, 65(Winter), pp.516-553

Tabachnick, B. G., \& Fidell, L. S. (2007), "Using Multivariate Statistics" (5th ed.). Boston, MA: Allyn \& Bacon.

Taylor, S., Claxton, J.D., (1994), “ Delays and the Dynamics of Service Evaluations”, Journal of the Academy of Marketing Science, Vol.22, No.3, pp.254-264

Tolpa,E.,(2012)," Measuring Customer Expectations Of Service Quality, Case Airline Industry", Master Thesis, Department of Information and Service Economy, School of Economics, Aalto University, Finland 
Wan D.T.W, Hui, T.K (2005). "Comparison Of Airline In-Flight Services", In Third AsiaPacific CHRIE conference held on 26-28 May 2005 at Kuala Lumpur, Malaysia. Kuala Lumpur, Malaysia

Wen C-H, Yeh W-Y, (2010), "Positioning Of International Air Passenger Carriers Using Multidimensional Scaling And Correspondence Analysis",Transport Journal,Winter,pp. 7-23.

Westbrook, R.A. and Oliver, R.L., (1991). "The Dimensionality of Consumption Emotion Patterns and Consumer Satisfaction," Journal of Consumer Research, 18(June), pp.84-91

Westbrook,R.A., (1987),'Product/Consumption-Based Affective Responses and Postpurchase Processes", Journal of Marketing Research, 24(August), pp.258-270

White,J.,(2012), "Building A Brand Management Service Vision", http://www.theideabrand.com/2012/10/18/building-a-brand-management-service-vision

Wicks, A. M., \& Roethlein, C. J. (2009),"A Satisfaction-Based Definition of Quality", Journal of Business \& Economic Studies, 15(1),pp.82-97.

Wiley, J. W. (1990), "Customer Satisfaction: A Supportive Work Environment And Its Financial Cost." Human Resource Planning. Vol. 14, pp. 117-27.

Wilson, A., Zeithaml, V. A., Bitner, M. J., \& Gremler, D. D. (2008),"Services Marketing. Integrating Customer Focus Across The Firm", Berkshire: Mcgraw-Hill

Wittman, M.D., (2014). "Are Low-Cost Carrier Passengers Less Likely To Complain About Service Quality?", Journal of Air Transport Management , 24, pp. 64-71

Wong,K.M., Musa,G., (2011) "Branding Satisfaction In The Airline Industry: A Comparative Study of Malaysia Airlines And Air Asia.",African Journal of Business Management Vol. 5(8), pp. 34103423

Yunus, N.S.N.M., Bojei, J., and Rashid, W.E.W., 2013, "Service Quality towards Customer Loyalty in Malaysia's Domestic Low Cost Airline Service", International Journal of e-Education, e-Business, e-Management and e-Learning, Vol. 3 ( 4), August, pp. 333-336.

Zeithaml, V.A., Parasuraman, A., Berry, L. (1985),"Problems and Strategies in Services Marketing", Journal of Marketing. Vol. 49, pp. 33-46. [61]

\section{Articles and Websites}

"Advertising vs Publicity." http://www.bmcommunications.com/ad_pub.htm (retrieved 05.09.14)

"AIRASIA is named as the World's Best Low-Cost Airline at the 2012, World Airline Awards held at Farnborough Air Show.” The World Airline Awards. 2012.(Retrieved 27 March 2014).

"Airlines to Welcome 3.6 Billion Passengers in 2016.", http://www.iata.org/pressroom/pr/pages/2012-12-06-01.aspx (retrieved 05.09.14)

“Air Asia Awards 2013.”, http://www.airasia.com/ot/en/about-us/awards.page, "Air Asia Awards 2013" (Retrieved 24.04.14)

"Aussie Watchdog Sues Airasia $\quad$ Over Hidden Fees.”,http://www.themalaysianinsider.com/malaysia/article/aussie-watchdog- sues-airasia-overhidden-fees (retrieved 14.05.14)

Bernama (13 July 2012). “Air Asia named Skytrax’s World Best Low Cost Airline.”,New Straits Times. (Retrieved 27 March 2014).

"Brand Perceptions", http://sonarstudios.com/brand-perception/ (Retrieved 23.04.14)

Gayle, Damien (5 August, 2012).,"Passenger Terror As Man Leaps Suddenly From Moving Plane In Emphatic Decision Not To Travel".,London: Daily Mail,Retrieved 10 February 2014.

“IATA Economic Benefit Summary",http://www.iata.org/publications/economics/Documents/890700aviation-economic-benefits-summary-report.pdf (retrieved 09.05.14)

"The Importance of Brand Perception." http://www.marketresearchforbeginners.com/the-importancebrand- perception/ (Retrieved 24.04.14)

The Star, "Malindo Confirms Plane Caught on Fire But Landed Safely in Subang". http://www.thestar.com.my/News/Nation/2014/03/26/Malindo-Air-fire-statement/ (retrieved 09.05.14)

"Malindo Air to Start Service on 22 March." http://www.thestar.com.my/News/Nation/2013/03/08/Malindo-Air-to-start- service-on-

March-22/ (Retrieved on 08.05.14)

“TurnaroundDefinition"http://www.thefreedictionary.com/turnaround (Retrieved 8 May 2014)

"Population of the World in 2014" http://www.worldometers.info/world population/wpc.php?utm_expid=49399927.scuhn054Q5WXvFD9uRG9Xw.2

\&utm_referrer=https\%3A\%2F\%2Fwww.google.com\%2F (retrieved 09.05.14) 